\title{
KEBIJAKAN TENTANG SEKOLAH ELIT ISLAM
}

\author{
Maemunah \\ (maemunah.88@gmail.com) \\ Dosen Sekolah Tinggi Ilmu Tarbiyah (STIT) Islamic Village Tangerang
}

\begin{abstract}
Abstrak: Munculnya sekolah elite / sekolah unggulan Islam, diharapkan dapat menjawab berbagai persoalan yang tengah dihadapi oleh internal umat Islam sendiri yakni keprihatinan terhadap mutu pendidikan Islam yang rendah dan sekaligus memberi solusi terhadap tantangan terhadap Iptek dan Imtak. Kebijakan pendidikan dirumuskan dengan mendasarkan diri pada landasan pemikiran yang lebih ilmiah empirik. Kajian ini menggunakan pola pendekatan yang beragam sesuai dengan faham teori yang dianut oleh masing-masing penentu kebijakan. Kebijakan demokratisasi pendidikan adalah kebijakan untuk menyeimbangkan komposisi peserta didik menurut kelompok status sosial ekonomi dan geografis guna mengurangi ketimpangan pendidikan. Dalam hal ini, dapat dinyatakan bahwa analisis terhadap kebijakan terkait sekolah elite; Sekolah Islam Unggulan yaitu ada pada kebijakan yang tertuang pada: UUD 1945 pasal 31 ayat 3, GBHN tahun 1992-2000 pada bagian agama Nomor 2, Pasal 5 ayat 1 UU SISDIKNAS 2003 BAB IV, Pasal 10 UU SISDIKNAS No. 202003 BAB IV, UU No. 20 Tahun 2003 Pasal 50 ayat 3, UU No. 20 Tahun 2003 Pasal 55 ayat 1, Peraturan Pemerintah No. 19 Tahun 2005 tentang Standar Nasional Pendidikan (SNP), UU No. 17 Tahun 2007.
\end{abstract}

Kata Kunci: Kebijakan Sekolah, Sekolat Elit, Sekolah Islam Unggulan.

\section{A. Pendahuluan}

Pendidikan merupakan suatu proses untuk memungkinkan peserta didik mengembangkan seluruh potensi yang dimiliki secara optimal, agar yang bersangkutan dapat menjalani kehidupan dengan efektif dan efisien, sehingga keberadaannya tidak saja berguna bagi diri pribadi tetapi juga bermanfaat bagi keluarga, masyarakat dan bangsanya. ${ }^{109}$

Pendidikan nasional merupakan salah satu tujuan pemerintah untuk mewujudkan cita-cita bangsa dan Negara Indonesia, hal tersebut telah diamanatkan dalam Pembukaan Undang-Undang Dasar 1945. Dalam hal ini, ingin mencerdaskan kehidupan bangsa Indonesia dalam seluruh aspek kehidupan agar lebih maju. Alasannya, hal itu sudah diamanatkan dalam Undang-Undang Dasar Republik Indonesia Pasal 31 ayat 1 yang berbunyi bahwa "Setiap warga negara

${ }^{109}$ Zamroni, Pendidikan Dan Demokrasi Dalam Transisi (Prakondisi Menuju Era Globalisasi), (Jakarta: Psp Muhammadiyah, 2007), 116. 
ISTIGHNA, Vol. 1, No 2, Juli 2018 P-ISSN 1979-2824

Homepage: http://e-journal.stit-islamic-village.ac.id/index.php/istighna

Maemunah

Kebijakan Tentang Sekolah Elit Islam

berhak memperoleh pengajaran”, dan juga terdapat pada ayat 2 bahwa "Pemerintah mengusahakan dan menyelenggarakan satu sistem pengajaran nasional, yang diatur denganUndang-Undang.,"110

Dalam memajukan pembangunan dalam bidang pendidikan, maka diperlukan sebuah komunitas yang kuat untuk melakukan revoulusi berpikir. Revolusi berpikir merupakan sebuah kesadaran kritis dan komprehensif untuk secara cepat mengubah tatanan pendidikan dari berkinerja seadanya ke pencapaian mutu secara signifikan. ${ }^{111}$ Dalam hal ini, ada tiga faktor penyebab rendahnya mutu pendidikan yaitu: kebijakan dan penyelenggaraan pendidikan nasional menggunakan pendekatan educational production function atau input-input analisis yang tidak konsisten, dalam hal ini pendidikan juga dilakukan secara sentralistik, sehingga peran serta masyarakat khususnya orang tua siswa dalam penyelenggaraan pendidikan sangat minim sekali. ${ }^{112}$

Pencapaian mutu pendidikan yang signifikan, banyak sekolah yang didirikan oleh masyarakat dan memberi nama sekolah elite atau sekolah unggulan. Sekolah yang mengatasnamakan dirinya sebagai sekolah elite atau unggulan tentu harus mempunyai kreteria dan standar tertentu yang berbeda dengan sekolah apada umumnya dan mendukung kualitas mutu dari tujuan pendidikan nasional.

Sekolah elite tersebut juga haruslah diakui keunggulannya oleh pemerintah dan masyarakat, bukan hanya oleh sekolah itu sendiri. Hal tersebut bukan hanya dilihat dari sarana prasarana saja, tetapi dapat terlihat dari proses pembelajarannya dan output-nya. Untuk membahas masalah sekolah elite atau sekolah unggulan tersebut, maka penullis akan memaparkan tentang kebijakan adanya sekolah elite atau unggulan, dan baberapa contoh sekolah islam unggulan yang sudah ada lama ada dan diakui oleh pemerintah dan masyarakat sekitarnya.

Maju dan berkembangnya pendidikan di Indonesia tidak lepas dari antusias masyarakat dalam mencari dan meneropong lembaga-lembaga pendidikan Islam

\footnotetext{
${ }^{110}$ A. Ferry T. Indratno, Kurikulum yang Mencerdaskan: Visi 2030 dan Pendidikan Alternatif (Jakarta: Kompas Media Nusantara, 2008), 10-11.

${ }^{111}$ Sudarwan Danim, Otonomi Manajemen Sekolah, (Bandung: Alfabeta, 2010), 16.

${ }^{112}$ Sudarwan Danim, Visi Baru Manajemen Sekolah: Dari Unit Birokrasi ke Lembaga Akademik (Jakarta: Bumi Aksara, 2006), 12.
} 
ISTIGHNA, Vol. 1, No 2, Juli 2018 P-ISSN 1979-2824

Homepage: http://e-journal.stit-islamic-village.ac.id/index.php/istighna

Maemunah

Kebijakan Tentang Sekolah Elit Islam

terkemuka yang dalam kacamata mereka memiliki daya tarik dan daya saing ilmu pengetahuan yang kelak dapat mengorbitkan anak-anak bangsa menjadi unggul dalam berbagai aspek. Keinginan untuk menyekolahkan anak di lembaga-lembaga pavorit, apalagi lembaga pendidikan yang diiringi dengan embel-embel "sekolah elite muslim, sekolah Islam Terpadu, atau sekolah konglomerat" merupakan incaran dan keinginan kuat dari orang tua untuk menyekolahkan generasi penerus mereka. Hal ini cukup dimaklumi, karena berkaca pada eksistensi madrasah sebagai lembaga pendidikan Islam selama ini mulai dipertanyakan, sehingga wajar kalau dewasa ini orang mulai melirik Sekolah-sekolah elite muslim, dengan harapan anak-anak nantinya memiliki bekal ilmu yang paripurna dan menjadi ahli-ahli agama dan pemimpin Islam. ${ }^{113}$

Dengan adanya terobosan dan inovasi sekolah elite, hal ini diperlukan untuk menanggapi kebutuhan peserta didik sekolah yang memiliki kemampuan dan kecerdasan luar biasa sekaligus mengeliminasi strategi pendidikan massal sebagaimana yang terjadi selama ini yang memberikan perlakuan dan pelayanan yang sama kepada semua peserta didik tanpa memperhatikan perbedaan kecakapan, minat, dan bakat yang dimilikinya.

Dalam makalah ini, akan dirumuskan masalahnya yang terkait dengan kebijakan sekolah elite / sekolah Islam uanggulan, yaitu: Bagimana kebijakan tentang sekolah elit dan sekolah Islam unggulan yang ada di Indonesia?

Makalah ini disusun oleh penulis dengan menggunakan pendekatan kepustakaan. Metode pengumpulan data yang digunakan yaitu dokumentasi berupa analisis dokumen-dokumen dalam bentuk buku-buku, literatur-literatur maupun jurnal-jurnal ilmiah yang berkaitan dengan topik yang ditulis dalam makalah ini, yaitu tentang kebijakan mengenai sekolah elite, sekolah Islam unggulan yang ada di Indonesia. Teknik analisis data yang digunakan yaitu teknik analisis interaktif terdiri dari tiga langkah yaitu reduksi data, display data dan verifikasi data.

\section{B. Pembahasan}

${ }^{113}$ Zuhairansyah Arifin: Dilema Pendidikan Islam Pada Sekolah Elite Muslim Antara Komersial Dan Marginalitas (Jurnal Potensia vol.13 Edisi 2 Juli-Desember 2014 h. 178. 
ISTIGHNA, Vol. 1, No 2, Juli 2018 P-ISSN 1979-2824

Homepage: http://e-journal.stit-islamic-village.ac.id/index.php/istighna

Maemunah

Kebijakan Tentang Sekolah Elit Islam

Dalam kamus besar bahasa Indonesia dijelaskan bahwa, yang dimaksud dengan bijak adalah akal budinya, pandai, mahir. ${ }^{114}$ Sedangkan kebijakan adalah rangkaian konsep dan asas yang menjadi garis besar dan dasar rencana dalam pelaksanaan suatu pekerjaan, kepemimpinan, dan cara bertindak (tentang pemerintahan, organisasi, dan sebagainya), pernyataan cita-cita, tujuan, prinsip, atau maksud sebagai garis pedoman untuk manajemen dalam usaha mencapai sasaran, garis haluan. ${ }^{115}$

Kebijakan (policy) secara etimologi (asal kata) diturunkan dari bahasa Yunani, yaitu "Polis" yang artinya kota (city). Dalam hal ini, kebijakan berkenaan dengan gagasan pengaturan organisasi dan merupakan pola formal yang samasama diterima pemerintah/lembaga sehingga dengan hal itu mereka berusaha mengejar tujuannya. ${ }^{116}$ Kebijakan juga merupakan keputusan pemerintah yang bersifat umum dan berlaku untuk seluruh anggota masyarakat. Kebijakan adalah aturan tertulis yang merupakan keputusan formal organisasi, yang bersifat mengikat, yang mengatur prilaku dengan tujuan untuk menciptakan tata nilai baru dalam masyarakat. ${ }^{117}$

Menurut Noeng Muhadjir, kebijakan merupakan upaya memecahkan problem sosial bagi kepentingan masyarakat atas asas keadilan dan kesejatheraan masyarakat. Dan dipilih kebijakan setidaknya harus memenuhi empat butir yakni: (1) tingkat hidup masyarakat meningkat, (2) terjadi keadilan: By the law, social justice, dan peluang prestasi dan kreasi individual, (3) diberikan peluang aktif partisipasi masyarakat (dalam membahas masalah, perencanaan, keputusan dan implementasi) dan (4) terjaminnya pengembangan berkelanjutan. ${ }^{118}$

Secara teoritik, suatu kebijakan pendidikan dirumuskan dengan mendasarkan diri pada landasan pemikiran yang lebih ilmiah empirik. Kajian ini menggunakan pola pendekatan yang beragam sesuai dengan faham teori yang dianut oleh masing-masing penentu kebijakan. Dalam 14 kajian ini, paling tidak

\footnotetext{
${ }^{114} \mathrm{Https}: / /$ Kbbi.Kemdikbud.Go.Id/Entri/Bijak.

${ }^{115} \mathrm{Https} / / /$ Kbbi.Kemdikbud.Go.Id/Entri/Kebijakan

${ }^{116}$ Syafaruddin, Efektivitas Kebijakan Pendidikan (Jakarta. Rineka Cipta, 2008), 75.

${ }^{117}$ Abidinsaid Zaina, Kebijakan Publik (Jakarta. Suara Bebas, 2006), 17

${ }^{118}$ Noeng Muhadjir, Perencanaan Dan Kebijakan Pengembangan Sumber Daya Manusia (Yogyakarta: Reka Sarasin, 1993), 15.
} 
ISTIGHNA, Vol. 1, No 2, Juli 2018 P-ISSN 1979-2824

Homepage: http://e-journal.stit-islamic-village.ac.id/index.php/istighna

Maemunah

Kebijakan Tentang Sekolah Elit Islam

ada dua pendekatan yang dapat direkomendasikan kepada para penentu/berwenang dalam merumuskan suatu kebijakan pendidikan. ${ }^{119}$

Penjabat pembuat kebijakan pendidikan adalah orang yang mempunyai wewenang yang sah untuk ikut serta dalam formulasi hingga penetapan kebijakan publik. Aktor atau lembaga-lembaga Negara dan pemerintah yang berwenang tersebut adalah MPR, DPR, Presiden, Pemerintah (Presiden sebagai pemerintah pusat, Menteri, Lembaga Pemerintah Non-Departemen, Direktorat Jenderal, Badan-badan Negara lain seperti Bank Sentral dan BUMN, Pemerintah Daerah Provinsi, Pemerintah Daerah Kota/Kabupaten, Kepala Desa), Dewan Perwakilan Daerah Provinsi, Dewan Perwakilan Daerah Kota/Kabupaten, Badan Perwakilan Desa. $^{120}$

Dorongan dalam menyelenggarakan pendidikan dari pemerintah ke masyarakat selama ini semakin kuat. Hal tersebut terjadi dengan alasan untuk menciptakan efiseinsi dan meningkatkan mutu pendidikan serta meningkatkan daya saing lulusan sekolahnya.

Makna dari ketiga konsep tersebut; efisiensi, mutu dan daya saing adalah kapitalisasi pendidikan. ${ }^{121}$ Lembaga pendidikan yang mempunyai modal besar yang akan dapat hidup, tumbuh dan berkembang. Sebaliknya lembaga pendidikan yang bermodal kecil bisa saja gulung tikar. Hal tersebut senada dengan suatu fakta semu bahwa "semakin mahal biaya pendidikan, semakin tinggi mutu pendidikan".

Pendidikan nasional mengakui pendidikan yang dibiayai oleh masyarakat (lembaga-lembaga swasta) sebagai mitra pemerintah dalam mencerdaskan kehidupan rakyat. Hingga saat ini, antara pendidikan negeri dan swasta belum berada di dalam mitra kesetaraan. Sesuai dengan bunyi UUD serta UU sistem pendidikan nasional masyarakat diberikan kesempatan untuk menyelenggarakan pendidikan bagi kelompoknya sendiri di dalam struktur sisitem pendidikan

${ }^{119}$ Arif Rohman, Politik Ideologi Pendidikan (Yogyakarta: Laksbang Mediatama Yogyakarta, 2009), 114.

${ }^{120}$ Martinis Yamin \& Maisah, Orientasi Baru Ilmu Pendidikan (Jakarta:Referansi, 2012), $125-126$

${ }^{121}$ Zamroni, Pendidikan Dan Demokrasi Dalam Transisi, 176. 
ISTIGHNA, Vol. 1, No 2, Juli 2018 P-ISSN 1979-2824

Homepage: http://e-journal.stit-islamic-village.ac.id/index.php/istighna

Maemunah

Kebijakan Tentang Sekolah Elit Islam

nasional. Sehingga manajemen pendidikan yang diselenggarakan oleh masyarakat harus berdiri di atas kemampuannya sendiri. ${ }^{122}$

Pendidikan berbasis masyarakat akan semakin kuat sejalan dengan keputusan politik yang diadakan pemerintah tentang desentralisasi pemerintah. Hal tersebut dilegitimasi dalam undang-undang nomor 20 tahun 2003 tentang Sistem pendidikan Nasional (SISDIKNAS).

Pada pasal 55 UU sisdiknas 2003 menyebutkan bahwa "Pendidikan berbasis masyarakat adalah penyelenggaraan pendidikan berdasarkan kekhasan agama, sosial, budaya, aspirasi, dan potensi masyarakat sebagai perwujudan pendidikan dari, oleh, dan untuk masyarakat."

Esensi pendidikan berbasis masyarakat dalam pasal tersebut, mempertegas bahwa; pertama, masyarakat berhak menyelenggarakan pendidikan berbasisi masyarakat pada pendidikan formal dan nonformal sesuai dengan kekhasan agama, lingkungan sosial, dan budaya untuk kepentingan masyarakat. Kedua, penyelenggara pendidikan berbasis masyarakat mengembangkan dan melaksanakan kurikulum dan evaluasi pendidikan, serta manajemen dan pendanaannya sesuai dengan SNP. Ketiga, dana penyelenggaraan pendidikan berbasis masyarakat dapat bersumber dari penyelenggara, masyarakat, pemerintah, pemerintah daerah dan/atau sumber lain yang tidak bertentangan dengan peraturan perundang-undangan yang berlaku. Keempat, lembaga pendidikan berbasis masyarakat dapat memperoleh bantuan teknis, subsidi dana, dan sumber daya lain secara adil dan merata dari pemerintah dan/atau pemerintah daerah. $^{123}$

Urgensi reformasi pendidikan nasional dalam mewujudkan visi masyarakat Indonesia, adalah mewujudkan suatu masyarakat madani Indonesia. ${ }^{124} \mathrm{Di}$ Indonesia, standar pendidikan dituangkan dalam Peraturan Pemerintah (PP) Nomor 19 Tahun 2005 tentang Standar Nasional Pendidikan (SNP) dalam PP ini

\footnotetext{
${ }^{122}$ Martinis Yamin \&Maisah, Orientasi Baru Ilmu Pendidikan, (Jakarta: Referensi, 2012), 68 .

${ }^{123}$ Sudarwan Danim, Otonomi Manajemen Sekolah, (Bandung: Alfabeta, 2010), 35-36.

${ }^{124}$ Syaukani, Pendiidkan Paspor Masa Depan (Perioritas Pembangunan Dalam Otonomi Daerah), (Jakarta: Nuansa Madani, 2006), 53.
} 
ISTIGHNA, Vol. 1, No 2, Juli 2018 P-ISSN 1979-2824

Homepage: http://e-journal.stit-islamic-village.ac.id/index.php/istighna

Maemunah

Kebijakan Tentang Sekolah Elit Islam

disebutkan bahwa SNP adalah kriteria minimal tentang sistem pendidikan di seluruh wilayah hukum Negara kesatuan Republik Indonesia.

Dalam hal ini, kata kunci untuk menggambarkan sistem pendidikan Nasional yang diperlukan dalam abad-abad mendatang adalah ialah pendidikan yang bermut. Mutu (quality) merupakan suatu istilah yang dinamis yang terus bergerak; jika bergerak maju dikatakan mutunya bertambah baik, sebaliknya jika bergerak mundur dikatakan mutunya merosot. Mutu dapat diartikan sebagai superioty atau exllence yaitu melebihi standar umum yang berlaku. ${ }^{125}$

Berikut ada beberapa kebijakan yang menjadi sandaran mengenai pendirian sekolah-sekolah elite, sekolah unggulan di Indonesia, diantarnaya sebagai berikut:

1. UUD 1945 pasal 31 ayat 3, yang menyebutkan bahwa pemerintah mengusahakan dan menyelenggarakan satu sistem pendidikan nasional yang meningkatkan keimanan dan ketaqwaan serta akhlaq mulia.

2. GBHN tahun 1992-2000 pada bagian agama nomor 2 dinyatakan, "Meningkatkan kualitas pendidikan agama dan melalui penyempurnaan sistem pendidikan agama sehingga lebih terpadu dan integral dengan sistim pendidikan nasional dengan didukung oleh sarana dan prasarana yang memadai".

3. Pasal 5 ayat 1 UU SISDIKNAS 2003 BAB IV "Setiap warga negara mempunyai hak yang sama untuk memperoleh pendidikan yang bermutu"

4. Pasal 10 UU SISDIKNAS No. 202003 BAB IV "Pemerintah dan Pemerintah Daerah berhak mengarahkan, membimbing dan membantu, dan mengawasi penyelenggaraan pendidikan sesuai dengan peraturan perundang-undangan yang berlaku".

5. UU No. 20 Tahun 2003 Pasal 50 ayat 3 yang menyatakan bahwa "Pemerintah dan atau Pemerintah Daerah menyelenggarakan sekurangkurangnya satu satuan pendidikan. Pada semua jenjang pendidikan untuk dikembangkan menjadi pendidikan berstandar internasional".

${ }^{125}$ Mastuhu,Sistem Pendidikan (Jakarta: Bumi Aksara, 2004), 65. 
ISTIGHNA, Vol. 1, No 2, Juli 2018 P-ISSN 1979-2824

Homepage: http://e-journal.stit-islamic-village.ac.id/index.php/istighna

Maemunah

Kebijakan Tentang Sekolah Elit Islam

6. UU No. 20 Tahun 2003 Pasal 55 ayat 1 "Hak masyarakat untuk menyelenggarakan pendidikan berbasis masyarakat pada pendidikan formal dan pendidikan non formal sesuai dengan kekhasan agama, lingkungan sosial dan budaya untuk kepentingan masyarakat”.

7. Peraturan Pemerintah No. 19 Tahun 2005 tentang Standar Nasional Pendidikan (SNP),

8. UU No. 17 Tahun 2007 tentang "Rencana Jangka Panjang Nasional Tahun 2008-2025 yang menetapkan tahapan skala prioritas utama dalam Rencana Pembangunan Jangka Menengah ke-1 tahun 2005-2009 yaitu untuk meningkatkan kualitas dan akses masyarakat terhadap layanan pendidikan".

Kebijakan demokratisasi demokrasi pendidikan adalah kebijakan untuk menyeimbangkan komposisi peserta didik menurut kelompok status sosial ekonomi dan geografis guna mengurangi ketimpangan pendidikan. Hakekat kebijakan ini adalah mengerem kecenderungan demokrasi pendidikan menuju anarki demi kelangsungan demokrasi itu sendiri. Wujud kebijakan ini mengurangi kebebasan peserta didik dalam memilih sekolah untuk jenjang pendidikan menengah dan alokasi peserta didik menurut domisili untuk jenjang perguruan tinggi. $^{126}$

Dalam perspektif sejarah, merebaknya sekolah elite muslim merupakan salah satu refleksi atas kelangkaan ulama, pemimpin dan ilmuan. Suatu masalah yang banyak dibicarakan masyarakat Indonesia, terutama karena telah meninggalnya ulama tua/senior, bahkan hampir tidak ditemukannya ulama setingkat para wali, ulama, dan umara zaman dulu. Berkembangnya sekolah elite muslim yang merupakan sekolah-sekolah unggulan Islam dimaksudkan untuk menciptakan sumber daya manusia (SDM) yang memiliki kemampuan sinergis di bidang Imtak dan Iptek. ${ }^{127}$

Munculnya sekolah elite muslim atau sekolah Islam unggulan dalam dunia pendidikan di Indonesia, pada awalnya belum terjadi kesenjangan yang signifikan

${ }^{126}$ Zamroni, Pendidikan Dan Demokrasi Dalam Transisi, 180.

${ }^{127} 3$ sinergi (Jurnal Populer Sumberdaya Manusia), No. 1 Volume I Januari-Maret 1998. 
ISTIGHNA, Vol. 1, No 2, Juli 2018 P-ISSN 1979-2824

Homepage: http://e-journal.stit-islamic-village.ac.id/index.php/istighna

Maemunah

Kebijakan Tentang Sekolah Elit Islam

di masyarakat. Akan tetapi, pada kenyataannya setelah sekolah ini mulai memperlihatkan kualitas dan output yang dapat bersaing di era ini, maka hal ini membuat para pengelola pendidikan, pihak yayasan di sekolah-sekolah elite muslim atau sekolah Islam unggulan untuk membuat planing dalam menghimpun dana untuk masuk ke sekolah tersebut dengan biaya yang cukup mahal.

Hal tersebut terlihat dengan mahalnya biaya masuk dan uang pembangunan dalam menjembatani uang sarana dan prasarana pendidikan untuk menunjang kegiatan pembelajaran. Dengan demikian, keputusan ini tentu akan memberatkan untuk orang tua yang berekonomi lemah atau menegah ke bawah dalam memasukan anaknya ke sekolah elite muslim atau sekolah Islam unggulan.

\section{Sekolah Elit : Sekolah Islam Unggulan}

Elitisme adalah sebuah konsep yang berasal dari kata "elite" yang berarti "kelompok kecil orang-orang yang mempunyai derajat tinggi, orang-orang terhormat, orang-orang terbaik, sesuatu yang dianggap paling baik atau mewah (tentang sesuatu benda atau barang)". Jadi, elitisme adalah sebuah paham atau ideologi atau "isme" tentang kalangan elite. Dengan kata lain, maksud elitisme pendidikan di sini adalah suatu pandangan yang melihat bahwa pendidikan itu hanyalah hak dan otoritas orang-orang elite saja, bukan orang-orang kecil dan terpinggirkan. Sementara pendidikan elitis adalah suatu bentuk pendidikan yang hanya diperuntukkan bagi kalangan terbatas yaitu kalangan "elite" saja. ${ }^{128}$

Dalam Kamus Besar Bahasa Indonesia dijelaskan bahwa yang dimaksud dengan unggul adalah lebih tinggi, pandai, kuat, dan sebagainya daripada yang lain, terbaik dan terutama. Sedangkan keunggulan artinya keadaan unggulan; kecakapan, kebaikan dan sebagainya yang lebih dari pada yang lain. ${ }^{129}$

Dalam konteks lembaga pendidikan atau istilah unggulan dapat dilekatkan pada Sekolah yang pada akhirnya terdapat adanya keinginan dan gairah baru dilingkungan organisasi pendidikan seperti sekolah untuk inovasi menjadi lebih

${ }^{128}$ Eka Yani Erfina, Kamus Lengkap Bahasa Indonesia Edisi Terbaru (Surabaya: Tiga Dua, T.Th), Hlm. 103 Dikutip Dari Andi Prastowo, Fenomena Pendidikan Elitis Dalam Sekolah/Madrasah Unggulan Berstandar Internasional (Jurnal Pendidikan Islam: Volume 1 Nomor , Junni 2012), 37.

${ }^{129}$ Peter Salim Dan Yenny Salim, Kamus Bahasa Indonesia Kontemporer (Jakarta: Modern English Press, 1991), 1685. 
ISTIGHNA, Vol. 1, No 2, Juli 2018 P-ISSN 1979-2824

Homepage: http://e-journal.stit-islamic-village.ac.id/index.php/istighna

Maemunah

Kebijakan Tentang Sekolah Elit Islam

baik kualitasnya dan unggul dari sekolah lainnya. Usaha ini juga menuntut sekolah tidak hanya harus memiliki cita-cita dan keinginan saja, tapi sekolah agar selalu memiliki kebutuhan berprestasi sehingga tercapai keunggulan dalam segala aspeknya. $^{130}$

Sekolah unggulan memiliki beberapa sebutan istilah atau term yang barangkali memiliki makna hampir serupa. Kata lain dari "unggulan" seringkali disebuat dengan istilah "model" atau "percontohan". Selain itu juga ada yang memakai istilah "terpadu", "laboratorium" atau "elite". Beberapa lembaga pendidikan Islam ada yang lebih senang memakai istilah "model" ketimbang "unggulan". Sehingga wajar saja kalau ada istilah "sekolah model", "sekolah percontohan", atau "sekolah terpadu". Sekolah Islam model (unggulan) merupakan representasi dari kebangkitan umat Islam untuk kalangan menengah. $^{131}$

Adapun yang menyebabkan munculnya sekolah unggulan adalah Sejak diberlakukannya Undang-undang No.20 Tahun 2003 tentang sistem pendidikan Nasional yang menempatkan Sekolah sebagai bagian dari subsistem pendidikan nasional. Sekolah pun dituntut untuk melakukan inovasi dan pembaharuan diri baik secara kelembagaan maupun dari sisi mutu output-nya. Mutu output yang diharapkan telah terkonsep dalam UUD 1945 pasal 31 ayat 3 yang menyebutkan bahwa pemerintah mengusahakan dan menyelenggarakan satu sistem pendidikan nasional yang meningkatkan keimanan dan ketaqwaan serta akhlaq mulia. ${ }^{132}$

Dalam perspektif ekonomi dan sosiologis, munculnya sekolah unggulan Islam, sekolah elite diharapkan dapat menjawab berbagai persoalan yang tengah dihadapi oleh internal umat Islam sendiri yakni keprihatinan terhadap mutu pendidikan Islam yang rendah dan sekaligus memberi solusi terhadap tantangan Iptek dan Imtak. Sebagai sekolah elite, mereka kebanyakan merebak di daerah perkotaan. Dan jika dilihat dari kaca mata ekonomi dan sosiologi, sekolah elit

\footnotetext{
${ }^{130}$ Agus Maimun Dan Agus Zaenul Fitri, Sekolahunggulan Lembaga Pendidikan Alternatif Di Era Kompetitif (Malang: Uin Maliki Press, 2010), 26.

${ }^{131}$ Azra, Azyumardi, Pendidikan Islam; Tradisi Dan Modernisasi Menuju Milenium Baru, (Jakarta, Logos, 1999), 69-75.

${ }^{132}$ Muhammad, "Konsep Pengembangan Sekolahunggulan", Kreatif, Vol. 4, No. 1 (Januari 2009), 35.
} 
ISTIGHNA, Vol. 1, No 2, Juli 2018 P-ISSN 1979-2824

Homepage: http://e-journal.stit-islamic-village.ac.id/index.php/istighna

Maemunah

Kebijakan Tentang Sekolah Elit Islam

memang pangsa pasarnya adalah anak-anak dari orangtua yang taraf penghidupannya sudah relatif mapan. Sehingga hubungan antara sekolah unggulan Islam dengan masyarakat terdapat titik kesamaan yaitu unsur budaya kelas tinggi. ${ }^{133}$

Sekolah unggulan dipandang memiliki peluang besar untuk memenuhi tuntutan masyarakat, hal tersebut dapat dilihat dari beberapa alasan sebagai berikut: pertama, terjadinya mobilitas sosial (yakni munculnya masyarakat menengah baru terutama kaum intelektual yang akhir-akhir ini mengalami perkembangan pesat), kedua, munculnya kesadaran baru dalam beragama (santrinisasi), terutama pada masyarakat perkotaan kelompok menengah atas, sebagai akibat dari proses re-Islamisasi yang dilakukan secara intens oleh organisasi-organisasi keagamaan, lembaga-lembaga dakwah atau yang dilakukan secara perorangan, dan ketiga, yaitu arus globalisasi dan modernisasi yang demikian cepat perlu disikapi secara arif. ${ }^{134}$

Berdasarkan nama-nama sekolah yang ditunjuk menjadi sekolah unggulan di seluruh wilayah Indonesia, tidak semua sekolah yang disebut unggulan itu memang dalam realitas empirisnya benar-benar unggul. Oleh sebab itu harus dibedakan dengan jelas antara sekolah unggulan dengan sekolah unggul. Pengertian unggul yang sesungguhnya itu lebih mengacu pada realitas empiris bahwa sekolah tersebut memiliki nilai lebih di antara yang lain yang dasar penilainanya diserahkan kepada masyarakat. Sedangkan sekolah unggulan adalah salah satu konstruksi politis yang diciptkan oleh penguasa untuk tujuan tertentu. $^{135}$

Sekolah unggul adalah sekolah dengan proses pembelajaran yang harus berada dalam dimensi kognitif yang menguasai pengetahuan dan bidang studi, dalam bidang keterampilan harus mampu untuk melakukan pekerjaan, memecahkan masalah, dan berpikir kreatif, dimensi nilai harus memiliki sikap

\footnotetext{
${ }^{133}$ Zuhairansyah Arifin: Dilema Pendidikan Islam Pada Sekolah Elite Muslim Antara Komersial Dan Marginalitas (Jurnal Potensia Vol.13 Edisi 2 Juli-Desember 2014), 180.

${ }^{134}$ Agus Maimun Dan Agus Zaenul Fitri, Sekolahunggulan Lembaga Pendidikan Alternatif Di Era Kompetitif, 10-11.

${ }^{135}$ Darmanigtyas, Pendidikan yang Memiskinkan (Yogyajarta: Galang Press, 2004), 200.
} 
ISTIGHNA, Vol. 1, No 2, Juli 2018 P-ISSN 1979-2824

Homepage: http://e-journal.stit-islamic-village.ac.id/index.php/istighna

Maemunah

Kebijakan Tentang Sekolah Elit Islam

terhadap diri, terhadap orang lain, terhadap lingkungan dan kepada Maha Pencipta, dimensi yang dibangun adalah hubungan yang dibangun oleh luaran pendidikan terutama dunia kerja dan masyarakat. ${ }^{136}$

Sekolah unggul diselenggarakan karena ada beberapa hal, antara lain sebagai berikut: ${ }^{137}$

1. Untuk meningkatkan nilai tambah (added value), yaitu bagaimana meningkatkan nilai tambah dalam rangka meningkatkan produktivitas nasional, pertumbuhan dan pemerataan ekonomi, sebagai upaya untuk memelihara dan meningkatkan pembangunan berkelanjutan.

2. Untuk melakukan pengkajian secara komprehensif dan mendalam terhadap terjadinya transformasi struktur masyarakat, dari masyarakat agraris ke masyarakat modern, menuju ke masyarakat industri yang menguasai teknologi dan informasi, yang implikasinya pada tuntutan dan pengembangan sumber daya manusia (SDM).

3. Persaingan global yang semakin ketat. yaitu bagaimana meningkatkan daya saing bangsa dalam menghasilkan karya-karya yang bermutu dan mampu bersaing sebagai hasil penguasaan ilmu pengetahuan, teknologi, dan seni (ipteks).

4. Munculnya kolonialisme baru di bidang iptek dan ekonomi menggantikan kolonialisme politik. Dengan demikian kolonialisme kini tidak lagi berbentuk fisik, melainkan dalam bentuk informasi. Ketergantungan bangsa kita pada bangsa lain merupakan suatu bentuk kolonialisme baru yang menjadi semacam virtual enemy yang telah masuk ke seluruh pelosok dunia ini. Semua tantangan ini menuntut SDM Indonesia agar meningkatkan serta memperluas pengetahuan dan wawasan keunggulan, keahlian yang profesional, ketrampilan dan kualitasnya

\footnotetext{
${ }^{136}$ Fahruddin, Became An Excellent Principal; Membentuk Siswa Berkarakter Unggul (Jakarta: PT. Elex Media Komputindo, 2014), 135.

${ }^{137}$ Indra Djati Sidi, Menuju Masyarakat Belajar: Menggagas Paradigma Baru Pendidikan (Jakarta: Logos Wacana Ilmu, 2001), 42-43.
} 
ISTIGHNA, Vol. 1, No 2, Juli 2018 P-ISSN 1979-2824

Homepage: http://e-journal.stit-islamic-village.ac.id/index.php/istighna

Maemunah

Kebijakan Tentang Sekolah Elit Islam

Dalam karakteristik esensial sekolah unggulan, sekolah harus memiliki keunggulan yang ditunjukkan dengan pengakuan internasional terhadap masukan (input), proses (process), dan hasil (output) pendidikan dalam berbagai aspek. Pengakuan tersebut dibuktikan dengan sertifikasi berpredikat baik dari salah satu anggota OECD dan atau negara maju lainnya yang mempunyai keunggulan tertentu dalam bidang pendidikan, diyakini telah memiliki reputasi mutu yang diakui secara internasional, serta lulusannya memiliki kemampuan daya saing internasional. Selain itu, setiap lulusan SBI diharapkan selain menguasai kompetensi dengan SNP di Indonesia, juga menguasai kemampuan-kemampuan kunci negara-negara maju tersebut. ${ }^{138}$

Untuk mengetahui keunggulan suatu sekolah, perlu adanya penilaian perbandingan antara input dan output dari sekolah tersebut. Hal ini perlu dilakukan agar dapat diketahui apakah siswa yang bersangkutan mengalami perubahan yang baik setelah melakukan proses pembelajaran di sekolah. Berdasarkan hal tersebut, penulis menawarkan konsep penilaian hubungan antara input dengan output. ${ }^{139}$

Keunggulan sekolah juga dengan menetapkan standar nasional pendidikan, yang meliputi standar isi, standar proses, standar kompetensi lulusan, standar pendidik dan tenaga kependidikan, standar sarana prasarana, standar pengelolaan, standar pembiayaan, dan standar penilaian pendidikan. ${ }^{140}$

Selain itu, keberadaan seorang guru bagi suatu bangsa amatlah penting, apalagi bagi suatu bangsa yang sedang membangun, terlebih-lebih bagi keberlangsungan hidup bangsa di tengah-tengah lintasan perjalanan zaman dengan teknologi yang kian canggih dan segala perubahan, serta pergeseran nilai yang

${ }^{138}$ Zainal Aqib, Membangun Prestise Sekolah Berstandar Nasional (Ssn) Dan Sekolah Berstandar Internasional (Sbi) (Bandung: Yrama Widya, 2010), 88.

${ }^{139}$ Petrus Trimantara, Sekolah Unggulan: Antara Kenyataan dan Impian, Jurnal Pendidikan Penabur, Volume 06 Nomor 08 (Juni, 2007), 6.

${ }^{140}$ Lihat Peraturan Pemerintah Republik Indonesia Nomor 19 Tahun 2005 Tentang Standar Pendidikan Nasional (Jakarta: fokus Media, 2010), 116. 
ISTIGHNA, Vol. 1, No 2, Juli 2018 P-ISSN 1979-2824

Homepage: http://e-journal.stit-islamic-village.ac.id/index.php/istighna

Maemunah

Kebijakan Tentang Sekolah Elit Islam

cenderung memberi nuansa kepada kehidupan yang meuntut ilmu dan seni dalam kadar dinamik untuk dapat mengadaptasikan diri. ${ }^{141}$

Hal tersebut juga telah dilakukan melalui dana pinjaman (loan) dari Asian Development Bank (ADB), Islamic Development Bank (IDB), dan Japan Bank for International Cooperation (JBIC), pendidkan Islam mulai dari tingkat dasar hingga perguruan tinggi kini sudah mulai banyak memiliki sumber daya manusia yang unggul, infrastruktur yang lengkap, sarana prasarana yang canggih, manajemen yang unggul, sehingga dapat bersaing dengan pendidikan umum. Berbagai kejuaraan lomba dalam bidang ilmu pengetahuan, teknologi, seni dan lainnya baik pada tingkat nasional maupun internasional sudah banyak yang diraih oleh para sisiwa dan mahasiswa perguruan tinggi Islam. ${ }^{142}$

Menurut Imron Arifin, unsur pendukung madrasah atau sekolah Islam berprestasi (unggul) itu setidaknya ada sembilan faktor, ${ }^{143}$ yaitu:

1. Faktor sarana dan prasarana. Meliputi: (a) fasilitas sekolah yang lengkap dan memadahi, (b) sumber belajar yang memadahi dan (c) sarana penunjang belajar yang memadahi.

2. Faktor guru. Meliputi: (a) tenaga guru mempunyai kualifikasi memadahi, (b) kesejahteraan guru terpenuhi, (c) rasio guru-murid ideal, (d) loyalitas dan komitmen tinggi, dan (e) motivasi dan semangat kerja guru tinggi.

3. Faktor murid. Meliputi: (a) pembelajaran yang terdiferensiasi, (b) kegiatan intra dan ekstrakulikuler bervariasi, (c) motivasi dan semangat belajar tinggi, (d) pemberdayaan belajar bermakna.

4. Faktor tatanan organisasi dan mekanisme kerja. Meliputi: (a) tatanan organisasi yang rasional dan relevan, (b) program organisasi yang rasional dan relevan, (c) mekanisme kerja yang jelas dan terorganisasi secara tepat.

\footnotetext{
${ }^{141}$ Moh. Uzer Usman, Menjadi Guru Profesional (Bandung: PT. Remaja Rosdakarya, 2011), 7.

${ }^{142}$ Abuddin Nata, Kapita Selekta Pendidikan Islam (Jakarta: PT. RajaGrafindo Persada, 2012), 115 .

${ }^{143}$ Arifin, Imron, Kepemimpinan Kepala Sekolah Dalam Mengelola Sekolah Berprestasi, (Yogyakarta: Aditya Media, 2008) Hal. 322-323.
} 
ISTIGHNA, Vol. 1, No 2, Juli 2018 P-ISSN 1979-2824

Homepage: http://e-journal.stit-islamic-village.ac.id/index.php/istighna

Maemunah

Kebijakan Tentang Sekolah Elit Islam

5. Faktor kemitraan. Meliputi: (a) kepercayaan dan harapan orangtua tinggi, (b) dukungan dan peran serta masyarakat tinggi, (c) dukungan dan bantuan pemerintah tinggi.

6. Faktor komitmen/sistem nilai. Meliputi: (a) budaya lokal yang saling mendukung, (b) nilai-nilai agama yang memicu timbulnya dukungan positif.

7. Faktor motivasi, iklim kerja dan semangat kerja. Meliputi: (a) motivasi berprestasi pada semua komunitas sekolah, (b) suasana, iklim kerja dan iklim belajar sehat dan positif, dan (c) semangat kerja dan berprestasi tinggi.

8. Faktor keterlibatan Wakil Kepala sekolah dan guru-guru. Meliputi: (a) keterwakilan kepala sekolah dalam pembuatan kebijakan dan pengimplementasiannya, (b) keterwakilan kepala sekolah dan guru-guru dalam menyusun kurikulum dan program-program sekolah, dan (c) keterlibatan wakil kepala sekolah dan guru-guru dalam perbaikan dan inovasi pembelajaran.

9. Faktor kepemimpinan kepala sekolah. Meliputi: (a) piawai memanfaatkan nilai religio-kultural, (b) piawai mengkomunikasikan visi, inisiatif, dan kreativitas, (c) piawai menimbulkan motivasi dan membangkitkan semangat, (d) piawai memperbaiki pembelajaran yang terdiferensiasi, (e) piawai menjadi pelopor dan teladan, dan (f) paiwai mengelola administrasi sekolah.

Dari Sembilan unsur pendukung tersebut, ada beberapa indikator yang menunjukkan sekolah itu unggul yaitu: ${ }^{144}$

1. Sekolah memiliki visi dan misi untuk meraih prestasi yang tinggi.

2. Semua personel sekolah memiliki komitmen yang tinggi untuk berprestasi yang tangguh dan professional.

3. Guru merupakan ujung tombak kegiatan sekolah karena berhadapan langsung dengan siswa. guru yang professional mampu mewujudkan

\footnotetext{
${ }^{144}$ Nanang Fattah, Konsep Manajemen Berbasis Sekolah dan Dewan Sekolah (Bandung: Bani Quraisy, 2004), 110-111.
} 
ISTIGHNA, Vol. 1, No 2, Juli 2018 P-ISSN 1979-2824

Homepage: http://e-journal.stit-islamic-village.ac.id/index.php/istighna

Maemunah

Kebijakan Tentang Sekolah Elit Islam

harapan-harapan orang tua dan kepal sekolah dalam kegiatan sehari-hari di dalam kelas.

4. Memiliki tujuan pencapaian filosofi yang jelas, yaitu tujuan filisofis diwujudkan dalam bentuk Visi dan Misi seluruh kegiatan sekolah. Tidak hanya itu, Visi dan Misi dapat dicerna dan dilaksanakan secara bersama oleh setiap elemen sekolah.

5. Lingkungan yang kondusif untuk pembelajaran. Lingkungan yang kondusif bukanlah hanya ruang kelas dengan berbagai fasilitas mewah, lingkungan tersebut bisa berada di manapun selama lingkungan tersebut dapat memberikan dimensi pemahaman belajar secara menyeluruh bagi siswa.

6. Jaringan organisasi yang baik dan solid. Baik itu organisasi guru, orang tua akan menambah wawasan dan kemampuan tiap anggotanya untuk belajar dan berkembang, serta perlu adanya dialog antar organisasi tersebut. Misalnya orang tua murid dengan forum guru dalam menjelaskan harapan dari guru dan kenyataan yang dialami guru di kelas.

7. Adanya komunikasi dan dukungan insentif dari orang tua murid dan masyarakat

Secara umum lembaga pendidikan Islam unggulan diformat dengan model dan gaya modern yang mengadopsi sisi-sisi meritokrasi dengan tanpa meninggalkan nilai-nilai pendidikan tradisional atau konvensional sebelumnya. Bahkan, lembaga pendidikan Islam unggulan mencoba menawarkan bentuk sintesa baru yang mengkolaborasi antara tujuan pendidikan umum dengan tujuan pendidikan (agama) Islam yang sepadan. Bentuk sintesa ini kemudian diiringi dengan dukungan kualitas akademik, sumber daya manusia (SDM), sarana prasarana, sumber pendanaan yang kuat serta penciptaan lingkungan yang baik. Kalau melihat gejala dan nuansa kebangkitan lembaga pendidikan Islam unggulan (madrasah dan sekolah Islam) nampaknya pada wilayah praksis baru muncul tahun 1980-an atau 1990-an. Baik madrasah maupun sekolah Islam unggulan mengadopsi dari sistem pendidikan umum, yang hal itu merupakan warisan dari sistem pendidikan kolonial Belanda, melalui modernisasi dari para pelaku dan 
ISTIGHNA, Vol. 1, No 2, Juli 2018 P-ISSN 1979-2824

Homepage: http://e-journal.stit-islamic-village.ac.id/index.php/istighna

Maemunah

Kebijakan Tentang Sekolah Elit Islam

praktisi pendidik orang muslim dengan menambahkan porsi materi agama Islam lebih banyak. ${ }^{145}$

Arah pembangunan sumber daya manusia juga menjadi hal penting dalam mendukung terciptanya sekolah unggulan. Arah pembangunan sumber daya manusia ditunjukan pada kualitas SDM secara komprehensif, meliputi aspek kepribadian, dan sikap mental, penguasaan ilmu dan teknologi, serta profesionalisme dan kompetensi yang kesemuanya dijiwai oleh nilai-nilai religius sesuai dengan ajaran agamanya. Dengan kata lain, pembangunan SDM harus meliputi pengembangan kecerdasan akal/ Intelegent Question (IQ), kecerdasan sosial/ Emotional Question (EQ), Kecerdsan Spiritual/ Spiritual Question (SQ), dan kecerdasan-kecerdasan lainnya secara seimbang. ${ }^{146}$

Dalam perspektif ekonomi dan sosiologis, munculnya sekolah unggulan Islam, sekolah elite diharapkan dapat menjawab berbagai persoalan yang tengah dihadapi oleh internal umat Islam sendiri yakni keprihatinan terhadap mutu pendidikan Islam yang rendah dan sekaligus memberi solusi terhadap tantangan Iptek dan Imtak. Sebagai sekolah elite, mereka kebanyakan merebak di daerah perkotaan. Dan jika dilihat dari kaca mata ekonomi dan sosiologi, sekolah elit memang pangsa pasarnya adalah anak-anak dari orangtua yang taraf penghidupannya sudah relatif mapan. Sehingga hubungan antara sekolah unggulan Islam dengan masyarakat terdapat titik kesamaan yaitu unsur budaya kelas tinggi. Secara finansial, sekolah elite muslim relatif mahal, hanya terjangkau bagi masyarakat kelas menengah ke atas. Secara sosiologis hal ini ada korelasi mengapa sekolah unggulan Islam atau sekolah elite muslim itu tergolong cepat berkembang dan membanggakan, karena secara finansial bagi sekolah-sekolah elite muslim tidak lagi ada masalah. ${ }^{147}$

Bersamaan dengan itu, para pengelola pendidikan Islam juga harus terus menigkatkan mutu lulusannya, senantiasa melakukan inovasi dan kreasi baru

\footnotetext{
${ }^{145}$ Nanang Budianto, Implementasi Pengembangan Madrasah Dan Sekolah Islam Unggulan Sebagai Upaya Peningkatan Kualitas Pendidikan Islam, (Jurnal Falasifa, Vol. 8 Nomor 1 Maret 2017), 110

${ }^{146}$ Abuddin Nata, Kapita Selekta Pendidikan Islam, 66-67.

${ }^{147}$ Zuhairansyah Arifin, Dilema Pendidikan Islam Pada Sekolah Elite Muslim Antara Komersial Dan Marginalitas, (Jurnal Potensia Vol.13 Edisi 2 Juli - Desember 2014), 180.
} 
ISTIGHNA, Vol. 1, No 2, Juli 2018 P-ISSN 1979-2824

Homepage: http://e-journal.stit-islamic-village.ac.id/index.php/istighna

Maemunah

Kebijakan Tentang Sekolah Elit Islam

sesuai dengan tuntutan masyarakat, dengan tetap memelihara jati dirinya sebagai pengemban misi ajaran Islam. ${ }^{148}$ Maka, lulusan pendidikan Islam diharapkan memenuhi kebutuhan yang diinginkan masyarakat dan tetap memiliki pribadi yang baik yang sesuai dengan pribadi yang baik memiliki akhlakul karimah.

Menurut Prof. Muzayyin Arifin, dalam menempuh jalur pendidikan yang bermutu, berorientasi Iptek dan Imtak, maka manusia harus mampu memproyeksikan keadaan masa depan ke dalam tiga kategori yakni: ${ }^{149}$

1. Masa Depan Sosio. Maksudnya adalah masa depan yang mengandung penomena prinsipal, antara lain penyebaran alternatif struktur rumah tangga yang lamban, sharing child-rearing (pengasuhan anak oleh orang tua), pandangan tentang posisi keibuan, hubungan-hubungan seksualitas dan moralitas sosial baru, serta interprerasi kembali tentang peranan agama dalam masyarakat. Makin banyak kaum wanita menjadi tenaga kerja. Penekanan hidup pada aspek-aspek sosial, penolakan umum terhadap penggunaan senjata penghancur massal. Terjadi perkawinan lintas suku dan agama.

2. Masa depan Tekno. Maksudnya adalah bahwa masyarakat masa depan akan dilanda pengaruh energi fisika tinggi, inovasi dan implikasinya yang cenderung lebih besar terhadap energi sinar laser. Bidang sibernetika, proses kontrol sistem-sistem mekanik, biologi, dan teknologi makin dimurnikan pemakaiannya

3. Masa depan Bio. Secara prinsipal ditandai dengan makin menghangatnya diskusi tentang pemakaian teknik modifikasi behavioral seperti kimia, elektronik, dan kejiwaan, serta isu-isu manipulasi genetika. Tugas-tugas orangtua (parenhood) dan keibuan semakin selektif berdasarkan prinsipprinsip genetika. Teknik-teknik pengendalian kelahiran. Makin menurunnya tantangan hidup (life span) disebabkan kekurangan makanan dan polusi lingkungan dan menurunnya tingkat kematian bayi. Ilmu-ilmu hayat, biokimia, dan ilmu-ilmu psikologi, besar kemungkinannya makin

\footnotetext{
${ }^{148}$ Abuddin Nata, Kapita Selekta Pendidikan Islam, 41.

${ }^{149}$ Muzayyin Arifin, Kapita Selekta Pendidikan Islam, (Jakarta: Bumi Aksara, 2003), 14-15.
} 
ISTIGHNA, Vol. 1, No 2, Juli 2018 P-ISSN 1979-2824

Homepage: http://e-journal.stit-islamic-village.ac.id/index.php/istighna

Maemunah

Kebijakan Tentang Sekolah Elit Islam

subur, sedang fisika dan teknik akan kehilangan status karena timbulnya kesadaran bahwa teknologi merupakan hikmah campuran (mixed blessings).

\section{Contoh Sekolah Elite: Sekolah Islam Unggulan}

Berikut ini ada beberapa contoh sekolah elite di sekolah Islam unggulan diantaranya adalah SMU Madania, Sekolah Insan Cendikia dan Sekolah AlAzhar.

\section{SMA Madania}

Yayasan Pendidikan Madania Indonesia (YPMI) didirikan pada tahun 1995 dengan pendiri: Prof. Dr. Nurcholish Madjid, Prof. Drs. Achmad Fuadi, dan Prof. Dr. Komaruddin Hidayat. Nama "Madania" berasal dari bahasa Arab "madaniah", kata dasar dari Madinah, yang berarti peradaban. Madinah sendiri berarti tempat peradaban, yang juga sering, ditafsirkan sebagai kota, tempat yang dihuni oleh masyarakat yang beradab, kepatuhan penuh, disiplin dan patuh pada Tuhan. Oleh karena itu, baik "madaniah" dan "medina" adalah kata-kata yang berasal dari kata daana-yadiinu-diinan, yang berarti patuh, patuh, patuh, dan pasrah. Madaniah dan madina juga berasal dari kata dasar yamdunu madana, madyinah, yang berarti membangun, yaitu membangun peradaban. Dengan semangat makna ini maka pada tahun 1996 YPMI mendirikan Madania School. Madania School adalah sekolah Indonesia yang menghargai perbedaan agama dan pemikiran, dan menghormati kebutuhan belajar individu dengan beragam kebutuhan dan kemampuan yang berbeda. Madania School menyediakan banyak pengalaman belajar dalam suasana kearifan Indonesia yang menghormati spiritualitas, tradisi, kebajikan, seni, budaya dan sejarah bangsa. Ini mengembangkan standar internasional dan didukung oleh sumber daya manusia, program pembelajaran dan fasilitas berkualitas. ${ }^{150}$

\section{Visi - Misi - Nilai - Kepercayaan Sekolah ${ }^{151}$}

Untuk tujuan mewujudkan apa yang terkandung dalam nama "Madania" dan sekaligus menjawab kondisi sosial pendidikan di tanah air, visi Sekolah Madania

\footnotetext{
${ }^{150} \mathrm{Https}: / /$ Www.Madania.Net/Pages/History_63

${ }^{151} \mathrm{Https}$ ://Www.Madania.Net/Pages/Vision-Mission-Values-Schoolbeliefs-_63
} 
ISTIGHNA, Vol. 1, No 2, Juli 2018 P-ISSN 1979-2824

Homepage: http://e-journal.stit-islamic-village.ac.id/index.php/istighna

Maemunah

Kebijakan Tentang Sekolah Elit Islam

dirumuskan demikian. Visi sekolah adalah: "Sekolah Indonesia Sejati untuk Generasi Pemimpin Berikutnya”.

Dengan visi tersebut, Madania School dirancang sebagai "sekolah pribumi Indonesia untuk mempersiapkan generasi pemimpin masa depan". Untuk mencapai visi itu, Madania kemudian merumuskan apa yang harus dilakukan dalam bentuk misi: "menghidupkan kembali kesadaran akan Tuhan, aktualisasi standar kelas dunia, hidup dengan karakter bangsawan, dan menghormati nilainilai Indonesia Ini berarti bahwa Madania mendidik murid-murid untuk membangkitkan kesadaran akan Tuhan, melaksanakan pendidikan internasional, hidup penuh martabat dan kemuliaan, serta menghargai nilai-nilai dan tradisi budaya Indonesia)."

Agar komunitas Madania tetap di jalur untuk mencapai visi Madania yang dijelaskan di atas, nilai-nilai Madania dikumpulkan: percaya pada Kebenaran (percaya pada kebenaran absolut), inklusivitas (terbuka), integritas (jujur dan amanah), dan intelek (menjadi pintar).

Believe in Truth bermaksud bahwa setiap warga negara memiliki keyakinan Madani kepada Tuhan Yang Maha Kuasa dan kemahakuasaan mutlak. Dia adalah awal dan tujuan setiap manusia. Inklusivitas menandakan bahwa setiap warga negara memiliki sikap terbuka dan toleransi Madania terhadap berbagai keyakinan, keyakinan dan pemikiran. Oleh karena itu, di Madania School, muridmurid dari semua agama di Indonesia diperlakukan secara adil dan bermartabat. Bahkan, anak-anak dengan kebutuhan khusus telah menerima dan diberi hak untuk belajar sesuai dengan kapasitas mereka.

Integritas menyatakan bahwa setiap warga Madani memiliki kejujuran dan bertindak sesuai dengan kata-kata, perbuatan, pemikiran dan pengetahuan mereka. Seseorang dianggap memiliki integritas yang bertindak sesuai dengan kebenaran yang dia tahu dan katakan dan menjauhkan dirinya dari perbuatan tercela. Intelek berarti wawasan holistik, bukan parsial, bukan ad hoc. Seseorang harus memiliki wawasan holistik yang luas dan mendalam, sehingga berbagai pandangan dan keputusannya dibuat berdasarkan kebijaksanaan. 
ISTIGHNA, Vol. 1, No 2, Juli 2018 P-ISSN 1979-2824

Homepage: http://e-journal.stit-islamic-village.ac.id/index.php/istighna

Maemunah

Kebijakan Tentang Sekolah Elit Islam

Berdasarkan latar belakang, makna, visi, dan nilai-nilai Madania yang dijelaskan di atas, program pembelajaran dirancang, disusun, dan dijalankan, sesuai dengan hukum dan peraturan yang berlaku di negara Indonesia. Dan dalam semangat semua itu, sekolah menjadi masyarakat Madania yang bercita-cita tinggi, miniatur Indonesia, di mana semua siswa - dan orang tua mereka - dan para guru serta semua karyawan Madania, terlepas dari agama, warna kulit, atau etnis asal, bisa hidup berdampingan, bekerja sama, dan mengajar dengan cinta, keterbukaan, dan keadilan. Ini rupanya apa yang Cak Nur bayangkan: masyarakat sipil, istilah yang sering dia gunakan untuk menyatakan.

Kepercayaan Sekolah Madania Anggota keluarga Madania: "Secara inklusif menerima kebenaran dan kebaikan dari sumber manapun, memiliki akhlak mulia terhadap diri mereka sendiri, orang lain, dan alam semesta, memiliki tindakan egaliter terhadap orang lain, bertanggung jawab atas sikap, kata-kata, dan tindakan mereka adalah pemecah masalah, mutakhir dengan inovasi terkini yang berharga dan aktif menciptakan lingkungan yang kondusif."

Pendidikan Madania berusaha memberikan fasilitas dan bimbingan bagi pertumbuhan intelegensi siswa secara utuh, sehingga ukuran keberhasilan anak didik tidak diukur secara seragam, melainkan sesuai dengan potensi dan minat masing-masing. Di Madania, pendidikan karakter sangat dipentingkan karena pendidikan life skill, disamping special skill, akan sangat diperlukan dalam kehidupan mendatang yang penuh perubahan. Pada 2003, menurut Wahyuni Nafis, Madania telah merumuskan Moral Values Education menjadi kurikulum, serta mengajarkan nilai-nilai, baik pada pelajaran agama maupun pelajaran umum lainnya. Pada tahun-tahun berikutnya, tahun 2007-2008, Madania menambah jam evaluasi proses belajar mengajar dari aspek kognitif, afektif maupun psikomotorik dengan cara semua guru harus terlibat menilai karakter siswa, misalnya: apakah kemandirian anak dan integritas anak dalam masing-masing pelajaran yang dipandu oleh guru-guru bersangkutan itu muncul (Wawancara dengan M. Wahyuni Nafis, MA; tanggal 8 Oktober di Parung, Bogor). ${ }^{152}$

${ }^{152}$ Mulyana, Pendidikan Nilai: Di Sekolah Madania Kabupaten Bogor (Jurnal "Al-Qalam" Volume 21 Nomor 2 Desember 2015), 310. 
ISTIGHNA, Vol. 1, No 2, Juli 2018 P-ISSN 1979-2824

Homepage: http://e-journal.stit-islamic-village.ac.id/index.php/istighna

Maemunah

Kebijakan Tentang Sekolah Elit Islam

\section{Insan Cendikia}

Berikut akan dijelaskan sejarah singkat tentang pendirian sekolah Insan Cendikia; ${ }^{153}$

Untuk memenuhi kebutuhan sumber daya manusia yang berkualitas tinggi dalam penguasaan IPTEK yang didasari nilai keimanan dan ketakwaan, pada tahun 1996 atas ide dari Prof. Dr. -Ing. Bacharuddin Jusuf Habibie, BPPT mendirikan Magnet School yang nantinya berubah namanya menjadi SMU Insan Cendekia di Serpong dan di Gorontalo melalui program penyetaraan IPTEK STEP (Science and Technology Equity Program) bagi sekolah-sekolah yang berada di lingkungan pondok pesantren. ${ }^{[2]}$

Pada tahun pelajaran pertama (1996/1997), penerimaan siswa SMU Insan Cendekia diprioritaskan bagi siswa-siswi SMU/MA kelas satu dan siswa-siswi lulusan SMP/MTs berprestasi yang berasal dari pondok pesantren dan sekolah Islam lainnya. Akan tetapi, mulai tahun pelajaran kedua (1997/1998) SMU Insan Cendekia memberi kesempatan pula kepada siswa-siswi SLTP umum dan MTs, baik negeri maupun swasta. ${ }^{[3]}$

Sejak tahun pelajaran 2000/2001 SMU Insan Cendekia, baik yang berada di Gorontalo maupun di Serpong, dilimpahkan pengelolaannya oleh BPPT kepada Departemen Agama RI. Untuk tetap mempertahankan ciri khas penguasaan IPTEK dan IMTAK, maka dalam pengelolaan dan pembinaannya, Departemen Agama dan BPPT terus melakukan kerja sama. Selanjutnya nama SMU Insan Cendekia ditransformasikan menjadi Madrasah Aliyah Insan Cendekia dengan tanpa mengurangi dan mengubah sistem pengajaran secara keseluruhan yang telah berjalan selama ini. ${ }^{[3]}$

Pada tahun 2001, dengan SK Menteri Agama RI, Nomor 490 Tahun 2001 MA Insan Cendekia Serpong dan Gorontalo berubah menjadi Madrasah Aliyah Negeri (MAN) Insan Cendekia Gorontalo dan Madrasah Aliyah Negeri (MAN) Insan Cendekia Serpong. Kemudian di provinsi Jambi MAN Cendikia Jambi mengubah namanya menjadi MAN Insan Cendekia Jambi. Peresmian perubahan nama ini dihadiri oleh Wamenag Prof. Dr. H. Nasaruddin Umar di kampus MAN

\footnotetext{
${ }^{153} \mathrm{Https}: / /$ Id.Wikipedia.Org/Wiki/Man_Insan_Cendekia
} 
ISTIGHNA, Vol. 1, No 2, Juli 2018 P-ISSN 1979-2824

Homepage: http://e-journal.stit-islamic-village.ac.id/index.php/istighna

Maemunah

Kebijakan Tentang Sekolah Elit Islam

Insan Cendekia Jambi - Kab. Muaro Jambi, Jumat (31/1) petang. Hadir dalam peresmian tersebut Wakil Gubernur Provinsi Jambi H. Fachrori Umar, anggota Komite III DPD RI Dra. Elviana, sejumlah pejabat eselon II pusat, Kakanwil Kemenag Provinsi Jambi Drs. H. Mahbub Daryanto, sejumlah Kepala Kantor Kemenag se Provinsi Jambi, dan Wakil Bupati Kabupaten Muaro Jambi. Dalam kesempatan tersebut, Wamenag menerima sertifikat ISO untuk MAN Insan Cendekia Jambi dan penyerahan bantuan dari Pemerintah Provinsi Jambi melalui Wakil Gubernur Provinsi Jambi untuk pembangunan 2 kelas baru, 2 asrama guru. ${ }^{[3]}$

Visi $^{154}$ : Terwujudnya sumber daya manusia yang berkualitas tinggi dalam keimanan dan ketakwaaan, menguasai ilmu pengetahuan dan teknologi, dan mampu mengaktualisasikan diri dalam kehidupan masyarakat.

Misi :

1. Menyiapkan calon pemimpin masa depan yang menguasai ilmu pengetahuan dan teknologi, mempunyai daya juang tinggi, mampu berkomunikasi dalam bahasa internasional, inovatif, dan mempunyai landasan iman dan takwa yang kuat.

2. Membentuk sumber daya tenaga pendidik dan tenaga kependidikan yang profesional.

3. Menjadikan MAN Insan Cendekia Serpong sebagai madrasah model dalam pengembangan pengajaran iptek dan imtak bagi lembaga pendidikan lainnya.

Profil Lulusan :

Aspek Sikap

- Memiliki keimanan dan ketaqwaan kepada Allah SWT.

- Memiliki nilai-nilai etika dan estetika.

- Memiliki nilai-nilai demokrasi, toleransi, dan humaniora.

Aspek Pengetahuan

- Memiliki pengetahuan faktual, konseptual, prosedural, dan metakognitif dalam ilmu pengetahuan, teknologi, seni, dan budaya

${ }^{154} \mathrm{Https} / / / \mathrm{Ic}$. Sch.Id/?Page_Id=13 
ISTIGHNA, Vol. 1, No 2, Juli 2018 P-ISSN 1979-2824

Homepage: http://e-journal.stit-islamic-village.ac.id/index.php/istighna

Maemunah Kebijakan Tentang Sekolah Elit Islam

dengan wawasan kemanusiaan, kebangsaan, kenegaraan, dan peradaban terkait penyebab serta dampak fenomena dan kejadian

- Menguasai ilmu pengetahuan, teknologi, dan kemampuan akademik untuk melanjutkan pendidikan ke jenjang yang lebih tinggi.

Aspek Keterampilan

- Memiliki kecakapan dalam bidang kepemimpinan

- Memiliki kemampuan pikir dan tindak yang efektif dan kreatif dalam ranah abstrak dan konkret sebagai pengembangan dari yang dipelajari di sekolah secara mandiri

- Memiliki keterampilan berkomunikasi (Bahasa Indonesia, Bahasa Inggris, Bahasa Arab), kecakapan hidup, dan mampu beradaptasi dengan perkembangan lingkungan sosial, budaya dan lingkungan alam, baik lokal, regional, maupun global.

- Memiliki kesehatan jasmani - rohani dan kemampuan kewirausahaan (entrepreneurship) yang bermanfaat untuk melaksanakan tugas dan kegiatan sehari-hari, terutama untuk membantu tugas atau aktivitas belajar.

\section{Al-Azhar}

Berikut ini akan dipaparkan mengenai sejarah tentang sekolah Al-Azhar yang juga merupakan sekolah Islam unggulan; ${ }^{155}$

Yayasan Pesantren Islam (YPI) Al-Azhar didirikan pada tanggal 7 April 1952 oleh 14 orang tokoh Islam dan pemuka masyarakat di Jakarta, dengan nama Yayasan Pesantren Islam?. Salah seorang pencetus gagasan pendirian yayasan ini adalah dr. Syamsuddin, Menteri Sosial RI ketika itu, yang didukung oleh Sjamsuridjal, yang pada waktu itu adalah Walikota Jakarta Raya. Sedangkan nama-nama pendiri yayasan selengkapnya adalah: Soedirdjo, Tan In Hok, Gazali Syahlan, H. Sjuaib Sastradiwirja, Abdullah Salim, Rais Chamis, Ganda, Kartapradja, Sardjono, H. Sulaiman Rasjid, Faray Martak, Jacub Rasjid, Hasan Argubie dan Hariri Hady.

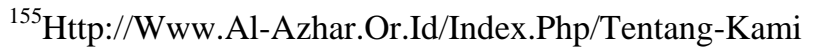


ISTIGHNA, Vol. 1, No 2, Juli 2018 P-ISSN 1979-2824

Homepage: http://e-journal.stit-islamic-village.ac.id/index.php/istighna

Maemunah

Kebijakan Tentang Sekolah Elit Islam

Yayasan Pesantren Islam memperoleh sebidang tanah yang terletak di daerah Kebayoran yang pada waktu itu merupakan daerah satelit dari Ibukota Jakarta. Di atas tanah itulah pada tahun 1953 mulai dilaksanakan pembangunan sebuah masjid besar dan rampung pada tahun 1958, yang kemudian dinamakan Masjid Agung Kebayoran.

Pada tahun 1961 Mahmoud Syaltout, Grand Syekh Al-Azhar Cairo ketika itu, mengunjungi tanah air sebagai tamu negara dan menyempatkan diri singgah di Masjid Agung Kebayoran. Kedatangan beliau disambut oleh sahabatnya Buya Prof. Dr. Hamka, Imam Masjid Agung Kebayoran, yang dua tahun sebelumnya dianugrahi gelar Doctor Honoris Causa (Ustadziyah Fakhriyah) oleh Universitas Al-Azhar Cairo. Dalam kesempatan itu Syekh Prof. Dr. Mahmoud Syaltout berkenan memberikan nama Al-Azhar untuk masjid tersebut sehingga nama resminya menjadi Masjid Agung Al-Azhar.

Seiring dengan perkembangan zaman dan kebutuhan umat, aktifitas di Masjid Agung Al-Azhar terus tumbuh dan berkembang. Awalnya kegiatan ibadah dan dakwah hanya diikuti oleh masyarakat sekitar, termasuk para pengayuh becak dan kuli bangunan. Kini jamaah Masjid Agung Al-Azhar datang dari berbagai lapisan umat, tidak saja mereka yang bermukim di kawasan elite Kebayoran Baru, Jakarta Selatan, bahkan dari luar daerah seperti Tangerang, Bekasi , Depok, Bogor dan lain-lain.

Semaraknya kegiatan-kegiatan pembinaan ummat dan syiar Islam di Masjid Agung Al-Azhar tidak dapat dilepaskan dari peran Buya Prof. Dr. Hamka sebagai Imam Besar di masjid ini. Figur Buya yang ceramah-ceramahnya senantiasa membawa kesejukan dengan pilihan kalimat-kalimat yang santun, telah mengikat perhatian ummat di berbagai pelosok, terutama melalui acara Kuliah Subuh yang disiarkan oleh RRI. Di samping membina berbagai aktifitas pengajian, majelis taklim, kursus-kursus agama Islam, Buya Prof. Dr. Hamka juga mendorong tumbuh dan berkembangnya sekolah-sekolah Islam Al-Azhar yang berpusat di kompleks Masjid Agung Al-Azhar. Kegiatan dakwah dan sekolah-sekolah tersebut, kian hari semakin mendapat tempat di hati masyarakat dan menambah 
ISTIGHNA, Vol. 1, No 2, Juli 2018 P-ISSN 1979-2824

Homepage: http://e-journal.stit-islamic-village.ac.id/index.php/istighna

Maemunah Kebijakan Tentang Sekolah Elit Islam

harum nama Al-Azhar di tengah-tengah ummat, tidak saja di Ibukota Jakarta dan sekitarnya tapi juga sampai ke berbagai daerah di tanah air.

Buya Prof. Dr. Hamka yang kebetulan bertempat tinggal di Jl. Raden Patah III, Kebayoran Baru, Jakarta Selatan, terletak bersebelahan dengan Masjid Agung Al-Azhar, telah memimpin pelaksanaan ibadah sehari-hari dan pengajian di masjid tersebut sejak pertama kali digunakan pada tahun 1958. Kajian tafsir AlQuran yang merupakan materi Kuliah Shubuh setiap hari di Masjid Agung AlAzhar dan kemudian dimuat secara bersambung pada majalah Gema Islam sejak tahun 1962, akhirnya diterbitkan dengan nama Tafsir Al-Azhar sebanyak 30 juz lengkap yang mendapat sambutan baik dari masyarakat hingga sekarang.

Saat ini terdapat lebih dari 25 kelompok kegiatan yang sehari-hari menyemarakkan kehidupan beragama di kompleks Masjid Agung Al-Azhar, dengan beragam bentuk dan corak aktifitas, seperti majelis taklim, pengajian, kursus, ceramah umum, diskusi, pelayanan kesehatan, pelayanan jenazah, bimbingan perjalanan haji dan umrah, pencak silat, madrasah diniyah (PIA), pendidikan formal dari taman kanak-kanak hingga perguruan tinggi sampai pada pelayanan perbankan dan travel biro.

\section{E. Penutup}

Dalam hal ini, dapat dinyatakan bahwa analisis terhadap kebijakan terkait sekolah elite. Sekolah Islam Unggulan yaitu ada pada kebijakan yang tertuang pada:

1. UUD 1945 pasal 31 ayat 3

2. GBHN tahun 1992-2000 pada bagian agama Nomor 2.

3. Pasal 5 ayat 1 UU SISDIKNAS 2003 BAB IV

4. Pasal 10 UU SISDIKNAS No. 202003 BAB IV

5. UU No. 20 Tahun 2003 Pasal 50 ayat 3

6. UU No. 20 Tahun 2003 Pasal 55 ayat 1

7. Peraturan Pemerintah No. 19 Tahun 2005 tentang Standar Nasional Pendidikan (SNP)

8. UU No. 17 Tahun 2007 
ISTIGHNA, Vol. 1, No 2, Juli 2018 P-ISSN 1979-2824

Homepage: http://e-journal.stit-islamic-village.ac.id/index.php/istighna

Maemunah

Kebijakan Tentang Sekolah Elit Islam

Dengan adanya kebijakan tersebut, Secara umum lembaga pendidikan Islam unggulan diformat dengan model dan gaya modern yang mengadopsi sisi-sisi meritokrasi dengan tanpa meninggalkan nilai-nilai pendidikan tradisional atau konvensional sebelumnya. Bahkan, lembaga pendidikan Islam unggulan mencoba menawarkan bentuk sintesa baru yang mengkolaborasi antara tujuan pendidikan umum dengan tujuan pendidikan (agama) Islam yang sepadan.

Munculnya sekolah unggulan Islam, sekolah elite diharapkan dapat menjawab berbagai persoalan yang tengah dihadapi oleh internal umat Islam sendiri yakni keprihatinan terhadap mutu pendidikan Islam yang rendah dan sekaligus memberi solusi terhadap tantangan Iptek dan Imtak.

\section{Daftar Pustaka}

Arifin, Imron. Kepemimpinan Kepala Sekolah Dalam Mengelola Sekolah Berprestasi, Yogyakarta: Aditya Media, 2008.

Arifin, Muzayyin, Kapita Selekta Pendidikan Islam, Jakarta: Bumi Aksara, 2003.

Aqib, Zainal. Membangun Prestise Sekolah Berstandar Nasional (SSN) dan Sekolah Berstandar Internasional (SBI) (Bandung: Yrama Widya, 2010.

Azra, Azyumardi, Pendidikan Islam; Tradisi Dan Modernisasi Menuju Milenium Baru, Jakarta: Logos, 1999.

Danim, Sudarwan, Otonomi Manajemen Sekolah. Bandung: Alfabeta, 2010. , Visi Baru Manajemen Sekolah: Dari Unit Birokrasi ke

Lembaga Akademik, Jakarta: Bumi Aksara, 2006.

Darmanigtyas. Pendidikan yang Memiskinkan. Yogyajarta: Galang Press, 2004.

Fahruddin. Became An Excellent Principal; Membentuk Siswa Berkarakter Unggul. Jakarta: PT. Elex Media Komputindo, 2014.

Fattah, Nanang, Konsep Manajemen Berbasis Sekolah dan Dewan Sekolah, Bandung: Bani Quraisy, 2004.

Indratno, A. Ferry T., Kurikulum yang Mencerdaskan: Visi 2030 dan Pendidikan Alternatif, Jakarta: Kompas Media Nusantara, 2008.

Maimun, Agus dan Agus Zaenul Fitri, Sekolahunggulan Lembaga Pendidikan Alternatif Di Era Kompetitif, Malang: Uin Maliki Press, 2010. 
ISTIGHNA, Vol. 1, No 2, Juli 2018 P-ISSN 1979-2824

Homepage: http://e-journal.stit-islamic-village.ac.id/index.php/istighna

Maemunah Kebijakan Tentang Sekolah Elit Islam

Mastuhu. Sistem Pendidikan, Jakarta: Bumi Aksara, 2004.

Muhadjir, Noeng. Perencanaan dan Kebijakan Pengembangan Sumber Daya Manusia, Yogyakarta: Reka Sarasin, 1993.

Nata, Abuddin, Kapita Selekta Pendidikan Islam. Jakarta: PT. RajaGrafindo Persada, 2012

Salim, Peter Dan Yenny Salim. Kamus Bahasa Indonesia Kontemporer . Jakarta: Modern English Press, 1991.

Sidi, Indra Djati, Menuju Masyarakat Belajar: Menggagas Paradigma Baru Pendidikan, Jakarta: Logos Wacana Ilmu, 2001.

Syafaruddin, Efektivitas Kebijakan Pendidikan. Jakarta. Rineka Cipta, 2008.

Syaukani. Pendidikan Paspor Masa Depan (Perioritas Pembangunan Dalam Otonomi Daerah). Jakarta: Nuansa Madani, 2006.

Yamin, Martinis \& Maisah, Orientasi Baru Ilmu Pendidikan. Jakarta:Referansi, 2012.

Yani Erfina, Eka. Kamus Lengkap Bahasa Indonesia Edisi Terbaru. Surabaya: Tiga Dua, t.th

Zaina, AbidinSaid. Kebijakan Publik (Jakarta. Suara Bebas, 2006.

Zamroni. Pendidikan Dan Demokrasi Dalam Transisi (Prakondisi Menuju Era Globalisasi). Jakarta: Psp Muhammadiyah, 2007.

3 Sinergi (Jurnal Populer Sumber daya Manusia), No. 1 Volume I Januari-Maret 1998.

Andi Prastowo, Fenomena Pendidikan Elitis dalam Sekolah/Madrasah Unggulan Berstandar Internasional (Jurnal Pendidikan Islam: Volume 1 Nomor, Juni 2012.

Muhammad, “Konsep Pengembangan Sekolahunggulan”, Kreatif, Vol. 4, No. 1, Januari 2009.

Petrus Trimantara, Sekolah Unggulan: Antara Kenyataan dan Impian, Jurnal Pendidikan Penabur, Volume 06 Nomor 08 (Juni, 2007), 6.

Zuhairansyah Arifin : Dilema Pendidikan Islam Pada Sekolah Elite Muslim Antara Komersial Dan Marginalitas (Jurnal Potensia vol.13 Edisi 2 JuliDesember 2014 
ISTIGHNA, Vol. 1, No 2, Juli 2018 P-ISSN 1979-2824

Homepage: http://e-journal.stit-islamic-village.ac.id/index.php/istighna

Maemunah Kebijakan Tentang Sekolah Elit Islam

Nanang Budianto, Implementasi Pengembangan Madrasah Dan Sekolah Islam Unggulan Sebagai Upaya Peningkatan Kualitas Pendidikan Islam, Jurnal Falasifa, Vol. 8 Nomor 1 Maret 2017.

https://www.madania.net/pages/history_63

https://www.madania.net/pages/vision-mission-values-schoolbeliefs-_63

https://id.wikipedia.org/wiki/MAN_Insan_Cendekia

https://ic.sch.id/?page_id=13

http://www.al-azhar.or.id/index.php/tentang-kami

https://kbbi.kemdikbud.go.id/. 